\title{
Reviews
}

\section{Removal of part of the eEF1A GTP binding domain induced translation errors in vitro}

\section{A.P. Pogribna, B.S. Negrutskii, A.V. Elskaya}

Institute of Molecular Biology and Genetics, NAS of Ukraine

150, Zabolotny Str., Kyiv, 03143, Ukraine

\begin{abstract}
Eukaryotic translation elongation factor $1 A(e E F 1 A)$ is one of the main components of the translation machinery acting at the elongation step. Oncogene PTI-1 which is expressed during prostate cancer development, codes the protein, homologous to eEF1A. In this paper the hypothesis is tested that the product of PTI-1 gene can influence the accuracy of translation. The ability of the PTI-1 protein analogue to stimulate misincorporation of leucine by ribosomes programmed with poly $(U)$ was demonstrated. This finding favors the hypothesis about the ability of the PTI-1 protein to influence translation accuracy in vivo.
\end{abstract}

Keywords: eukaryotic translation elongation factor $1 A$, oncogene PTI-1, ribosome, tRNA.

Introduction. Eukaryotic translation elongation factor $1 \mathrm{~A}(\mathrm{eEF} 1 \mathrm{~A})$ is a guanine nucleotide-binding protein which provides correct recognition of mRNA codon by tRNA anticodon on the ribosome. Besides its main role in translation, eEF1A may be also involved into other cell processes, such as signal transduction [1],

(C) A.P. Pogribna, B.S. Negrutskii, A.V. Elskaya , 2006 cytoskeleton organization [2, 3], as well as apoptosis [4], carcinogenesis [5, 6], virus infection [7], diabetes [8, 9].

Recently more data on participation of eEF1A in carcinogenesis appear. In particular, the connection between eEF1A and oncogenesis was found at human prostate carcinoma research [10]. Dominant oncogene was found in tumor tissues, which was later called PTI-1(prostate tumor inducing gene-1). It was shown 


\begin{tabular}{|c|c|c|c|c|c|c|}
\hline $\begin{array}{l}\mathrm{eEF} 1 \mathrm{~A} 1 \\
\Delta \mathrm{eEF} 1 \mathrm{~A} 1\end{array}$ & 1 & & & & & \\
\hline & & & & & & \\
\hline & 51 & $\mathrm{VL}$ & ERG & ITIDISLWKF & ETTKYYITII & DAPGHRDFIK \\
\hline $\mathrm{EF}_{1 \mathrm{~A} 1}$ & 1 & & ......G & ITIDISLWKF & ETTKYYITII & FIK \\
\hline$\Gamma I-1$ & 1 & & .......MQSERG & ITIDISLWKF & ETTKYYITII & DAP \\
\hline$A 1$ & 101 & NMITGTSQAD & CAVLIVAAGV & GEFEAGISKN & GQTREHALLA & QLIV \\
\hline $1 \mathrm{~A} 1$ & 32 & NMITGTSQAD & CAVLIVAAGV & GEFEAGISKN & GQTREHALLA & KQLIV \\
\hline ГІ -1 & 37 & NMITGTSQAD & CAVLI & EAGISKN & GQTREHALLA & QLIV \\
\hline A1 & 151 & GVNKMDSTEP & AYSEK & AYIKK & $\mathrm{VPF}$ & GDN \\
\hline $\mathrm{A} 1$ & 82 & GVNKMDSTEP & AYSEF & VKEVSAYIKK & ATVPF & WHGDN \\
\hline$I-1$ & 87 & GVNKMDSTEP & AYSEKRYDEI & VKEVSAYIKK & IGYNPATVPF & GDN \\
\hline A1 & 201 & MLEPS PNMPW & FKGW & VSLLE & $\mathrm{SPPTR}$ & LPL \\
\hline A1 & 132 & MLEPS & FKGWKVERKE & GNASC & LPPTR & RLPL \\
\hline$I-1$ & 137 & MLEPS PNMPW & FKGWKVERKE & GNASGVSLLE & ALDTILPPTR & PTDKPLRLPL \\
\hline & 251 & QDVYKIGGIG & TVPVG & ILRPGMVVTF & APVNITTEVK & IEALS \\
\hline $1 \mathrm{~A} 1$ & 182 & QDVYK & TVPVC & ILRPGMVVTF & TTEVK & EALS \\
\hline-1 & 87 & QDVYKI & VETG & ILRPGMVVTF & APVNITTEVK & ALLS \\
\hline A1 & 301 & EALPGDNVGF & NVKNVSVKDI & RRGNVCGDSK & SDPPQEAAQF & LNHP \\
\hline $1 \mathrm{~A} 1$ & 232 & EALPGDNVGF & NVKNVSVKDI & RRGNVCGDSK & SDPPQEAAQF & ILNHP \\
\hline-1 & 237 & EALPGDNVGF & NVKNVSVKDI & RRGNVCGDSK & SDPPQEAAQF & TSQVI ILNHP \\
\hline & 351 & GYSPV & AHIAC & KFAEI & RLEDN & $\mathrm{DAA}$ \\
\hline & 282 & GQISAGYSPV & IDCHTAHIAC & KFAELKEKID & RRSGKKLEDN & PKSLKSG \\
\hline & 287 & GQISAGYSPV & IDCHTAHIAC & KFAELKEKID & RRSGKKLEDN & PKSLKSGDAA \\
\hline & 401 & IVEMVPGKPM & CVESFSQYPP & LGRFAVRDMR & GTVAVGVIKN & VEKKSGGAGK \\
\hline $1 \mathrm{~A} 1$ & 332 & IVEMVPGKPM & CVESFSQYPP & LGRFAVRDMR & GTVAVGVIKN & VEKKSGGAGK \\
\hline & 337 & IVEMVPGKPM & CVESFSQYPP & LGRFAVRDMR & GTVAVGVIKN & VEKKSGGAGK \\
\hline & 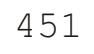 & VTKSAQKAQK & AGK & & & \\
\hline & 382 & VTKSAQKAQK & AGK & & & \\
\hline & 87 & VTKSAQKAQK & AGK & & & \\
\hline
\end{tabular}

Fig. 1 The comparison of amino acid sequences for native eEF1A, trypsin-modified eEF1A and protein PTI-1, derived from nucleotide sequence of the PTI-1 mRNA.

that PTI-1 gene contains the sequence of 630 nucleotide bases (n.b.) in 5 -not coding area, which is $87 \%$ identical to the sequence of 23 S ribosome RNA of Mycoplasma hyopneumoniae. It is interesting that the coding sequence of this gene is $99.25 \%$ identical to the sequence of the eEF1A protein, shortened at $\mathrm{N}$-end of 67 amino acid residues and with three additional amino acids added (Fig.1) [11]. Therefore, PTI-1 oncogene can code a protein with 398 a.a., which is the homologue of eEF1A. As the sequence absent in PTI-1 comparing to eEF1A is a part of GTP-binding site of translation elongation factor, it is logical to suppose that this modification may lead to changes in PTI-1 functioning compared with eEF1A.

Minding the mentioned above, the hypothesis has been put forward that PTI-1 represents the new oncogene class, the transformational properties of which may be mediated by the following mechanisms: 1) action on the translation accuracy, resulting in synthesis of "wrong" polypeptides, , in particular, the regulatory ones, which could effect tumor development [12]; 2) influence on cytoskeletal proteins due to the changes in a known ability of eEF1A to interact with actin and tubulin; 3 ) the changes in one or several 
different pathways of signal transduction possibly involving PTI-1 as a G-protein [13].

It is known that eEF1A mutations may have direct influence on the reading frame shift and the increased incorporation of wrong amino acids in Sacharomyces cerevisae. For example, the substitution of only one amino acid in eEF1A sequence changes the level of selectivity and correct codon-anticodon interaction of aminoacyl-tRNA in the process of translation [14]. Therefore, the appearance in tumor cells of eEF1A homologue, which is coded by PTI-1, seems to be the reason for decrease of translation accuracy. The goal of this work was to test principal possibility of PTI-1 analogous protein to affect the translation accuracy and therefore, to investigate whether the protein is capable of increasing the misincorporation of leucine by ribosomes programmed with poly(U).

Materials and Methods. eEF1A and eEF2 preparations were obtained from rabbit liver as earlier described [15]. Preparations of rabbit liver ribosomal subunits and of bovine liver total tRNA were obtained as in [16].

Limited tryptic cleavage of rabbit liver eEF1A was performed as earlier described [15].

Aminoacylation of total tRNA was performed in the buffer - 30mM imidazole, pH 7.5 (Sigma, USA); 5mM $\mathrm{MgCl}_{2}, 100 \mathrm{mM} \mathrm{KCl}, 3 \mathrm{mM}$ dithiothreitol (Amersham, Sweden); 3mM ATP, pH 7.0; $40 \mathrm{mM}\left[{ }^{14} \mathrm{C}\right] \mathrm{Phe}$ (Amersham), $120 \mathrm{Mg}$ of bovine liver total tRNA and $200 \mathrm{mg}$ of total aminoacyl-tRNA synthetase preparation purified from rabbit liver. Aminoacylation was performed for $15 \mathrm{~min}$ at $371 \mathrm{C}$, followed by cooling on ice bath. Aliquots of this mixture served as a source of aminoacyl-tRNA in the system of poly(U) translation.

Incorporation of $\left[{ }^{14} \mathrm{C}\right]$ phenylalanine into product of poly $(U)$ translation was performed at $371 \mathrm{C}$ in the buffer: 50mM HEPES, pH7.6 (Fluka, the Czech Republic), $8 \mathrm{mM} \mathrm{MgCl}, 70 \mathrm{mM} \mathrm{KCl}, 10 \%$ glycerol, $1 \mathrm{mM} \mathrm{ATP}$, pH7.0 (Sigma), 0.4mM GTP, pH7.5, 40 $\mathrm{mg} / \mathrm{ml}$ creatine phosphokinase (Serva), $10 \mathrm{mM}$ creatine phosphate (Serva), $10 \mathrm{mg} / \mathrm{sample}$ of poly(U) (Sigma). Translational mixture $(100 \mathrm{ml})$ also contained $15 \mathrm{pmol} 40 \mathrm{~S}$ and 25 pmol $60 S$ ribosomal subunits, 60 pmol eEF2, different quantities eEF1A or $\triangle \mathrm{eEF} 1 \mathrm{~A}$, and $50 \mathrm{ml}$ of mixture for aminoacylation containing $120 \mathrm{Mg}$ of total tRNA aminoacylated with $\left[{ }^{14} \mathrm{C}\right] \mathrm{Phe}$. The reaction was stopped by adding $2 \mathrm{ml}$ of cooled TCA. Then the reaction mixture was heated (10min, 901C) for aminoacyl-tRNA destruction and cooled on ice bath. Precipitates were placed on GF/C filters (Whatman, USA) and rinsed by $30 \mathrm{ml}$ of cold $3 \%$ TCA.
Misincorporation of leucine to the poly(U) translation product was investigated in the same buffer as in the case with phenylalanine except for increasing $\mathrm{MgCl}_{2}$ concentration up to $13 \mathrm{mM}$.

The radioactivity of dry filters was measured in Optiphase scintillator using RackBeta meter 1219 (LKB, Sweden). Effectiveness of $\left[{ }^{14} \mathrm{C}\right]$ calculation on filters was $71 \%,\left[{ }^{3} \mathrm{H}\right]-26 \%$.

Results and Discussion. Since the product of limited tryptic cleavage of eEF1A and hypothetical oncogene product PTI-1 are 99\% identical (Fig.1), eEF1A, modified by tripsin, was used as a model of PTI-1 protein.

We have determined that $\triangle \mathrm{EEF} 1 \mathrm{~A}$, regardless of the absence of $1 / 3$ GTP/GDP-binding domain, preserved its functional activity in GTP, GDP, and tRNA binding to some degree, as well as it could maintain poly(U) translation in cell-free translation system, obtained from individual components [15]. The task of current work was to determine whether the presence of PTI-1 analogue protein in cell-free translation system influences the ability of the system to misincorporate leucine instead of phenylalanine during poly(U) translation.

Unlike in our early experiments [15], where the preparation of individual phenylalanine yeast tRNA was used for the measurement of the $\triangle \mathrm{eEF} 1 \mathrm{~A}$ translational activity, in this work we used the preparation of total tRNA of bovine liver as this preparation contained tRNA $^{\text {Phe }}$ and tRNA ${ }^{\text {Leu }}$ which is the obligatory condition for the translational errors study in the poly $(U)$ translational system.

The optimal concentration of eEF1A or $\triangle \mathrm{eEF} 1 \mathrm{~A}$ for poly $(U)$ translation was determined (Fig. 2). It is important to state that, while using both yeast and bovine liver tRNA, even the addition of $\triangle \mathrm{eEF} 1 \mathrm{~A}$ extra amounts did not allow increasing the activity of cell-free translational system to the level which was observed in the presence of the native eEF1A, i.e. the splitting of almost $1 / 3$ of GTP-binding eEF1A domain led to partial loss of the eEF1A activity as judged by estimation of the translation kinetics.

The kinetics of poly $(U)$ translation with the participation of eEF1A and $\triangle \mathrm{eEF1A}$ was studied (Fig.3) using total tRNA aminoacylated with $\left[{ }^{14} \mathrm{C}\right] \mathrm{Phe}$. The rate of incorporation of $\left[{ }^{14} \mathrm{C}\right]$ phenylalanine into TCA insoluble precipitate in the presence of eEF1A was $\sim 1.12$ pmoles Phe/min, and in the presence of $\triangle \mathrm{eEF} 1 \mathrm{~A}$ $\sim 0.61 \mathrm{pmoles} \mathrm{Phe} / \mathrm{min}$ at $8 \mathrm{mM} \mathrm{Mg}$ ions concentration in the reaction mixture. 


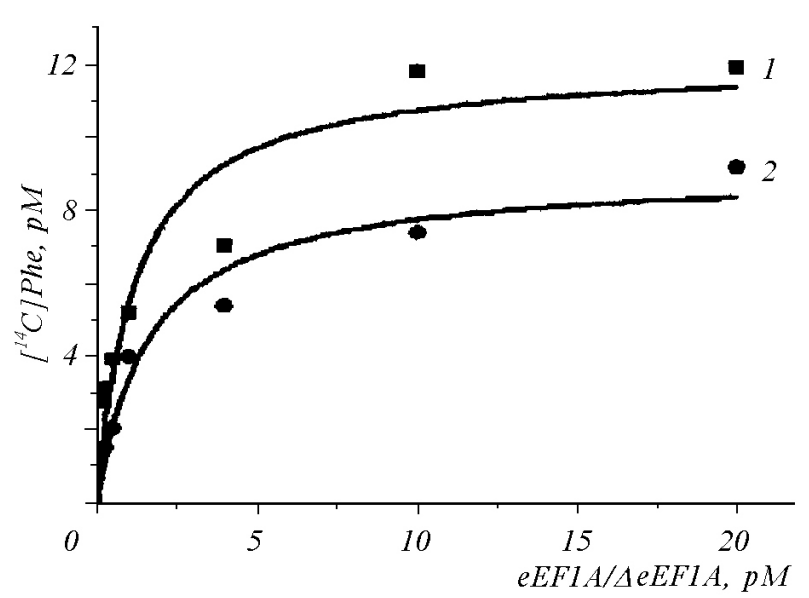

Fig.2 Polyphenylalanine synthesis at $8 \mathrm{mM} \mathrm{MgCl}_{2}$ in cell-free translation system at different eEF1A (1) and $\triangle \mathrm{eEF} 1 \mathrm{~A}$

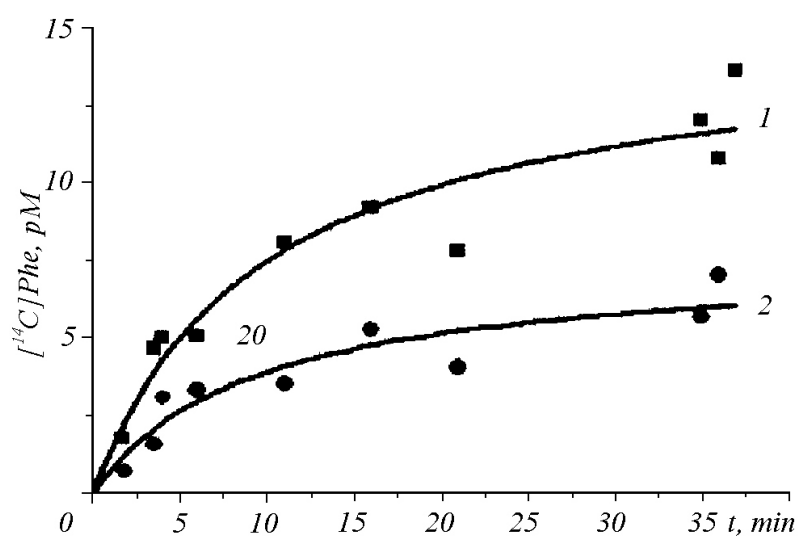

Fig. 3 The kinetics of polyphenylalanine synthesis in cell-free translation system in the presence of eEF1A (1) or $\triangle \mathrm{eEF} 1 \mathrm{~A}$ (2) (14 $\mathrm{pM} /$ sample) at $8 \mathrm{mM} \mathrm{MgCl}_{2}$ concentration.

It is known that leucine misincorporation into poly $(U)$ translation product in cell-free protein-synthesizing systems form Escherichia coli [17] and wheat germs is induced by the increase in $\mathrm{Mg}^{2+}$ ions concentration [18]. However, since the optimal $\mathrm{MgCl}_{2}$ concentration for translation error study in the protein-synthesizing system of higher eukaryotes remained not determined, we investigated the influence of $\mathrm{Mg}^{2+}$ concentration on the phenylalanine and leucine incorporation into the product of poly $(U)$ translation (Fig.4). The highest level of leucine misincorporation during poly $(U)$ translation in this system was observed at $\mathrm{MgCl}_{2}$ concentrations from 12 to $14 \mathrm{mM}$.

The translation error index was determined as the ratio of misincorporated leucine to incorporated phenylalanine. The incorporation of amino acids into
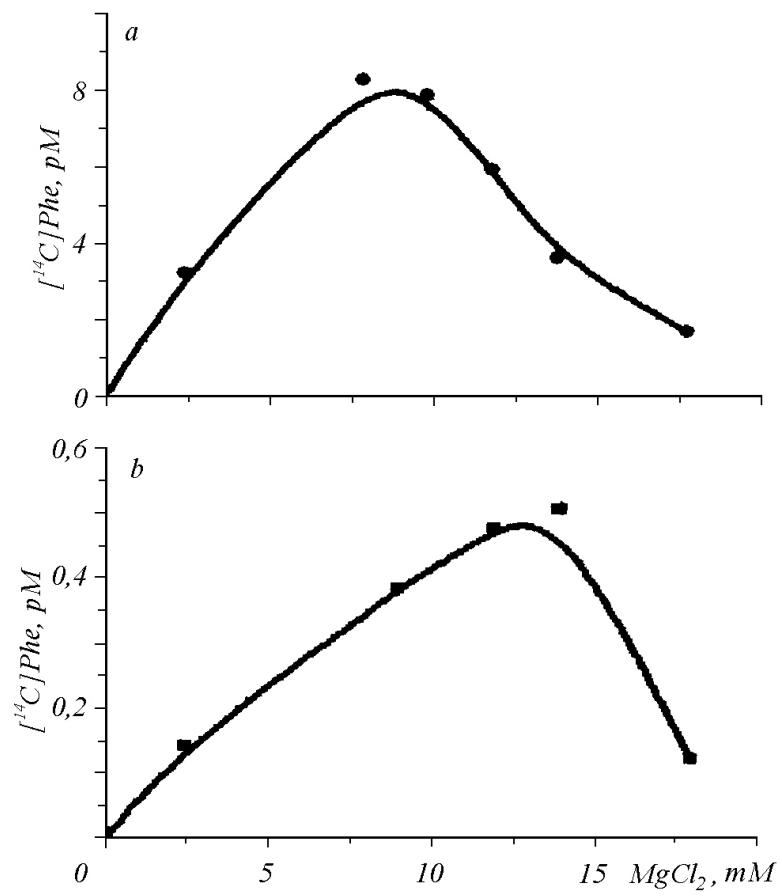

Fig. 4 The dependence of incorporation of $\left[{ }^{14} \mathrm{C}\right] \mathrm{Phe}(\mathrm{a})$ and $\left[{ }^{3} \mathrm{H}\right] \mathrm{Leu}(\mathrm{b})$ in TCA insoluble precipitate from $\mathrm{MgCl}_{2}$ in the presence of full-sized eEF1A.

TCA-insoluble product was studied at initial rate of poly $(\mathrm{U})$ translation by $80 \mathrm{~S}$ ribosomes. $4 \mathrm{~min}$ incubation time fulfilled completely the initial rate conditions and allowed obtaining the sufficient amount of radioactivity in TCA-precipitate. The experimental results are shown in the Table. As it is seen, the replacement of eEF1A for $\triangle \mathrm{eEF} 1 \mathrm{~A}$ in the translation system leads to almost 6 times increase in the level of translation errors.

Therefore, the obtained data are in favor of the hypothesis considering the possibility of translational errors induction at the presence of the PTI-1 protein product. It is not excluded, that such mechanism may explain known translation errors increase during oncogenesis [10].

As it was mentioned above, first 67 amino acid residues are absent in $\mathrm{PTI}-1$ protein in the comparison to eEF1A. How can it influence the translation errors? On the example of yeast eEF1A mutagenesis the involvement of amino acid residues Asn153 and Asp156 [20], as well as Glu122 and Thrl42 [21], to the control of accuracy has been shown. It is interesting that according to the X-ray analysis data, all these residues are located near or participate directly in the formation of GDP-binding "pocket" of eEF1A. These residues provide the interaction with GDP guanine ring, at the same time, on the basis of X-ray analysis, amino 


\begin{tabular}{c|c|c|c}
\hline Factor & $\begin{array}{c}\text { Initial rate of incorporation of } \\
{\left[{ }^{14} \mathrm{C}\right] \mathrm{Phe}, \mathrm{pM} / \mathrm{min}}\end{array}$ & $\begin{array}{c}\text { Initial rate of misincorporation of } \\
{\left[{ }^{3} \mathrm{H}\right] \mathrm{Leu}, \mathrm{pM} / \mathrm{min}}\end{array}$ & $\begin{array}{c}\text { Translation error index } \\
\left(\left[{ }^{3} \mathrm{H}\right] \mathrm{Leu} /\left[{ }^{14} \mathrm{C}\right] \mathrm{Phe}\right)\end{array}$ \\
\hline eEF1A & 1.12 & 0.11 & 0.1 \\
$\Delta$ EEF1A & 0.61 & 0.35 & 0.57
\end{tabular}

acids may interact with the phosphate group of the same GDP molecule in the area between the $15^{\text {th }}$ and $19^{\text {th }}$ eEF1A residues [22], i.e. those amino acids that are not present in $\triangle \mathrm{eEF} 1 \mathrm{~A}$ or in $\mathrm{PTI}-1$ protein. It is logical to assume that if this part of GDP-binding site is absent in $\triangle \mathrm{eEF} 1 \mathrm{~A}$, then the affinity of the mentioned protein for GDP be decreased. That notion is supported by our data and the data of scientific literature $[15,23]$. Therefore, the decreased GDP/GTP binding capability of the PTI-1 protein may contribute to the increase of error level.

Therefore, we show for the first time that the loss of the part of GTP-binding domain, responsible for binding of the GTP/GDP phosphate groups, may be important for correct eEF1A functioning in translation. The results of work show that $\triangle \mathrm{eEF} 1 \mathrm{~A}$, used as a model of PTI-1 protein product, is capable to participate in the protein biosynthesis in vitro, however causing the increase in misincorporation of amino acids by ribosomes. Therefore, it could not be excluded that the appearance of the PTI-1 protein in tumor cells may lead to the synthesis of erroneous proteins with altered functions or no function at all. This is in favor of translational mechanism of the PTI-1 oncogene participation in carcinogenesis. Elucidation of the possible participation of PTI-1 in the induction of translational errors in vivo is the task for further investigations.

\section{А.П. Погребноя, Б. С. Негруцкий, А. В. Ельская}

Удаление части GTP-связывающего домена эукариотного фактора элонгации трансляции 1 А приводит к индукции трансляционных ошибок in vitro

\section{Резюме}

Эукариотный фрактор элонгации трансляции 1A(eEF1A) является одним из главных компонентов аппарата белкового синтеза на стадии элонгации. Онкоген PTI-1, экспрессия которого обнаружена при раке предстательной железы человека, кодирует белок - гомолог еEF1A. Проверена гипотеза о том, что белковый продукт гена PTI-1 влияет на точность трансляции. Продемонстрирована способность аналога PTI-1 стимулировать ошибочное включение лейцина рибосомами, программи- роваными поли(U)-матрицей, что подтверждает возможность продукта гена PTI-1 влиять на точность трансляции in vivo.

Ключевые слова: эукариотный фрактор элонгации трансляции 1A, онкоген PTI-1, рибосома $\mathrm{mPHK.}$

\section{REFERENCES:}

1. Yang W., Boss W. F. Regulation of phosphatidylinositol 4-kinase by the protein activator PIK-A49. Activation requires phosphorylation of PIK-A49 // J. Biol. Chem.-1994.-269.-P. 3852-3857.

2. Shiina N., Gotoh Y., Kubomura N., Iwamatsu A., Nishida E. Microtubule severing by elongation factor 1 alpha // Science.-1994.-266.-P. 282-285.

3. Kurasawa Y., Hanyu K., Watanabe Y., Numata O. F-actin bundling activity of Tetrahymena elongation factor $1 \alpha$ is regulated by $\mathrm{Ca}^{2+} /$ calmodulin // J. Biol. Chem.-1996.-119.-P. 791-798.

4. Ruest L.-B., Marcotte R., Wang E. Peptide elongation factor eEF1A-2/S1 expression in cultured differentiated myotubes and its protective effect against caspase- 3 mediated apoptosis // J. Biol. Chem.-2002.-277.-P. 5418-5425.

5. Grant A. G., Flomen R. M., Tizard M. L., Grant D. A. Differential screening of a human pancreatic adenocarcinoma lambda gt11 expression library has identified increased transcription of elongation factor EF-1 alpha in tumor cells // Int. J. Cancer.-1992.-50.-P. 740-745.

6. Edmonds B. T., Wyckoff J., Yeung Y. G., Wang Y., Stanley E. $R$., Jones J., Segall J., Condeelis J. Elongation factor-1 alpha is an overexpressed actin binding protein in a metastatic rat mammary adenocarcinoma // J. Cell. Science.-1996.-109.-P. 2705-2714.

7. Cimarelli A., Luban J. Translation elongation factor 1-alpha interacts specifically with human immunodeficiency virus type 1 Gag polyprotein // J. Virol.-1999.-73.-P. 5388-5401.

8. Reynet C., Kahn C. R. Unbalanced expression of the different subunits of elongation factor 1 in diabetic skeletal muscle // Proc. Nat. Acad. Sci. USA.-2001.-98.-P. 3422-3427.

9. Ejiri S-I. Moonlighting functions of polypeptide elongation factor 1: From actin bundling to zinc finger protein R1-associated nuclear localization // Biosci. Biotechnol. and Biochem.-2002.-66.-P. 1-21.

10. Shen R., Su Z. Z., Olsson C. A., Fisher P. B. Identification of the human prostatic carcinoma oncogene PTI-1 by rapid 
expression cloning and differential RNA display // Proc. Nat. Acad. Sci. USA.-1995.-92.-P. 6778-6782.

11. Mansilla F., Hansen L. L., Jakobsen H., Clarck B. F. C., Kjeldgaard N. O., Knudsen Ch. R. Deconstructing PTI-1: PTI-1 is a truncated, but not mutated, form of translation elongation factor 1A1, eEF1A1 // J. Biochem. Biophys.-2005.-1727.-P. $116-124$

12. Zao-zhong S., Goldstein N. I., Fisher P. B. Antisense inhibition of the PTI-1 oncogene reverses cancer phenotypes // Proc. Nat. Acad. Sci. USA.-1998.-95.-P. 1764-1769.

13. Gopalkrishnam R. V., Su Z. Z., Goldstein N. I., Fisher P. B. Translation infidelity and human cancer: role of PTI-1 oncogene // Int. J. Biochem. Cell Biol.-1999.-31.-P. 151-162.

14. Sandbaken M. G., Gulbertson M. R. Mutations in elongation factor EF-1\{alpha\} affect the frequency of frameshifting and amino acid isincorporation in Saccharomyces cerevisiae /I Genetics.-1988.-120.-P. 923-934.

15. Погребная А. П., Горчаков С. В., Негруцкий Б. С. Сравнительный анализ функциональной активности нативной и модифицированной трипсином фоом эукариотического фактора элонгации трансляции 1А // Біополімери і клітина.-2004.-20, № 4.-С. 300-307.

16. El'skaya A. V., Ovcharenko G. V., Pal'chevskii S. S., Petrushenko Z. M., Triana-Alonso F. J., Nierhaus K. H. Three tRNA binding sites in rabbit liver ribosomes and role of the intrinsic ATPase in $80 \mathrm{~S}$ ribosomes from higher eukaryotes // Biochemistry.-1997.-36.-P. 10492-10497.

17. Agafonov D. E., Spirin A. S. The ribosome-associated inhibitor A reduces translation errors // Biochem. and Biophys. Res. Communs.-2004.-320.-P. 354-358.
18. El'skaya A. V., Soldatkin A. P. The accuracy of Poly(U) translation by different eukaryotic tRNAs // FEBS Lett.-1983.-164.-P. 93-96.

19. Abbott C. M., Proud C. G. Translation factors in sickness and health // Trends Biochem. Sci.-2004.-29.-P. 25-31.

20. Cavallius J., Merrick W. C. Site-directed mutagenesis of yeast eEF1A. Viable mutants with altered nucleotide specificity // J. Biol. Chem.-1998.-273.-P. 28752-28758.

21. Carr-Schmid A., Durko N., Cavallius J., Merrick W. C., Kinzy T. $G$. Mutations in a GTP-binding motif of eukaryotic elongation factor $1 \mathrm{~A}$ reduce both translational fidelity and the requirement for nucleotide exchange // J. Biol. Chem.-1999.-274.-P. 30297-30302.

22. Vitagliano L., Ruggiero A., Masullo M., Cantiello P., Arcari P., Zagari $A$. The crystal structure of Sulfolobus solfataricus elongation factor $1 \alpha$ in complex with magnesium amd GDP // Biochemistry.-2004.-43.-P. 6630-6636.

23. Kinzy T. G., Merrick W. C. Characterization of a limited trypsin digestion form of eukaryotic elongation factor $1 \alpha / / \mathrm{J}$. Biol Chem.-1991.-266.-P. 4099-4110.

УДК 577.217

Надійшла до редакції 11.07.05 